\title{
Enrolment and logistical challenges in TaMoVac 01 Phase I/II HIV trial despite the completion of an earlier (HIVIS-03 trial trial) in Dar es Salaam
}

\author{
M Ngatoluwa ${ }^{1}$, P Munseri ${ }^{1 *}$, M Janabi ${ }^{1}$, F Mhalu' ${ }^{1}$, E Sandstrom² ${ }^{2}$ M Bakari ${ }^{1}$ \\ From AIDS Vaccine 2012 \\ Boston, MA, USA. 9-12 September 2012
}

\section{Background}

Participation of sub-Saharan countries in HIV vaccine trials is important in the fight against HIV/AIDS, and has to be sustained by continued trials. Experiences from earlier trials are expected to influence the design and the performance of subsequent trials. Following completion of HIVIS-03 trial, TaMoVac- 01 trial was initiated. We compare enrolment experiences between the two trials.

\section{Methods}

The HIVIS-03 trial, conducted between 2007 - 2010 recruited 60 volunteers from the Police force in Dar es Salaam.

The subsequent TaMoVac- 01 trial has recruited 62 volunteers from the Police and Prisons force, and youths at IDC.

\section{Results}

Enrollment of volunteers into the HIVIS-03 took 12 months while the TaMoVac-01 trial took 13 months.

Screened: enrolled ratio was 3:1for HIVIS-03 trail, while for TaMoVac-01 8:1. Reasons for screen-out in the TaMoVac-01 trial were influence of family, misconception, clinical and laboratory abnormalities.

Recruitment of females was a challenge in the HIVIS03 trial, but was unnoticed in the TMV-01 trial, this could be due to inclusion of youths. Misconceptions in the Police force remain an obstacle to recruitment despite regular education sessions.

Other challenges were: Poor adherence to schedules, due to competing prioritization of employment

${ }^{1}$ Muhimbili University of Health and Allied Sciences, Tanzania, United Republic of

Full list of author information is available at the end of the article requirements; difficulties in communication with volunteers without phones.

Most challenges were addressed through collaboration with the concerned authorities in the respective cohorts.

\section{Conclusion}

Recruitment challenges continued in the TMV-01 trial despite our experiences with HIVIS-03 trial. Enhanced Community engagement and timely action by the researchers is necessary to ensure a smooth conduct of the trials.

\section{Author details}

${ }^{1}$ Muhimbili University of Health and Allied Sciences, Tanzania, United

Republic of. ${ }^{2}$ Karolinska Institutet, Sweden.

Published: 13 September 2012

doi:10.1186/1742-4690-9-S2-P153

Cite this article as: Ngatoluwa et al:: Enrolment and logistical challenges in TaMoVac 01 Phase I/II HIV trial despite the completion of an earlier (HIVIS-03 trial trial) in Dar es Salaam. Retrovirology 2012 9(Suppl 2):P153.

Submit your next manuscript to BioMed Central and take full advantage of:

- Convenient online submission

- Thorough peer review

- No space constraints or color figure charges

- Immediate publication on acceptance

- Inclusion in PubMed, CAS, Scopus and Google Scholar

- Research which is freely available for redistribution

Submit your manuscript at www.biomedcentral.com/submit C) Biomed Central 